JURNAL PENDIDIKAN, p-ISSN 2715-095X, e-ISSN 2686-5041

Volume 30, No.2, Juli 2021 (207-218)

Online: http://journal.univetbantara.ac.id/index.php/jp

\title{
Peningkatan Kemampuan Menyusun RPP Bagi Guru Kelas dan Mata Pelajaran Di SD Negeri 2 Trayu Kecamatan Banyudono Kabupaten Boyolali Melalui Supervisi Akademik Metode Direktif Semester II Tahun 2021
}

\author{
Daliyo \\ SD Negeri 2 Trayu Kecamatan Banyudono Kabupaten Boyolali, \\ E-mail: dadaliyo294@gmail.com
}

Received: Mey 26, 2021

Accepted: Juni 1, 2021

Online Published: Juni 26, 2021

\begin{abstract}
Abstrak: Penelitian ini bertujuan untuk: (1) mendeskripsikan langkah-langkah pelaksanaan supervisi akademik dengan pendekatan kelompok metode direktif guna meningkatkan kemampuan guru kelas dan guru mata pelajaran dalam penyusunan RPP; dan (2) meningkatkan kemampuan guru kelas dan guru mata pelajaran dalam penyusunan RPP di SD Negeri 2 Trayu Kecamatan Banyudono Kabupaten Boyolali melalui supervisi akademik dengan pendekatan kelompok metode direktif. Penelitian ini merupakan penelitian tindakan. Penelitian dilakukan di SD Negeri 2 Trayu Kecamatan Banyudono Kabupaten Boyolali pada semester 2 tahun pelajaran 2020/2021 selama 3 (tiga) bulan. Subjek penelitian adalah 8 (delapan) orang guru kelas dan guru mata pelajaran di SD Negeri 2 Trayu Kecamatan Banyudono Kabupaten Boyolali. Prosedur penelitian dalam penelitian tindakan ini pada intinya mengacu pada desain penelitian yang digunakan, yaitu: (1) perencanaan; (2) pelaksanaan; (3) observasi; dan (4) refleksi hasil tindakan. Penelitian ini menyimpulkan bahwa: (1) Langkah-langkah pelaksanaan supervisi akademik pendekatan kelompok dengan metode direktif untuk meningkatkan kemampuan guru dalam penyusunan RPP adalah sebagai berikut: (a) Menyampaikan pengumuman kepada guru tentang akan dilaksanakannya kegiatan supervisi akademik mengenai peningkatan kemampuan guru dalam penyusunan RPP; (b) Mempersiapkan materi bimbingan berupa penyusunan silabus dan RPP sesuai dengan Kurikulum 13; (c) Menyampaikan materi bimbingan tentang cara penyusunan silabus dan RPP sesuai dengan Kurikulum 13 dengan benar; dan (d) Mempersiapkan instrumen supervisi baik instrumen wawancara maupun instrumen pengamatan; (2) Supervisi akademik dengan pendekatan kelompok metode direktif dapat meningkatkan guru kelas dan guru mata pelajaran dalam penyusunan RPP di SD Negeri 2 Trayu Kecamatan Banyudono Kabupaten Boyolali. Hal ini ditunjukkan dengan meningkatnya nilai rata-rata hasil penilaian RPP yang diperoleh guru maupun jumlah guru dengan kemampuan menyusun RPP kategori Amat Baik (A) dan Baik (B) pada setiap siklus tindakan yang dilakukan. Nilai rata-rata hasil penilaian RPP mengalami peningkatan dari sebesar 67.95 pada kondisi awal, meningkat menjadi 74.55 pada tindakan Siklus I, dan kemudian meningkat menjadi 81.12 pada tindakan Siklus II. Jumlah guru dengan kemampuan menyusun RPP kategori Amat Baik (A) dan Baik (B) mengalami peningkatan dari sebanyak $31.25 \%$ pada kondisi awal, meningkat menjadi $50.00 \%$ pada tindakan Siklus I, kemudian meningkat menjadi $81.25 \%$ pada tindakan Siklus II.
\end{abstract}

Kata-kata Kunci: Penyusunan RPP, supervisi akademik, pendekatan kelompok, metode direktif 


\title{
Improved Ability to Compile RPP for Classroom Teachers and Subjects in SD Negeri 2 Trayu, Banyudono District, Boyolali Regency through Academic Supervision of Semester II Directive Methods Year 2021
}

\author{
Daliyo \\ SD Negeri 2 Trayu Kecamatan Banyudono Kabupaten Boyolali, \\ E-mail: dadaliyo294@gmail.com
}

\begin{abstract}
This study aims to: (1) describe the steps of implementing academic supervision using a group approach with the directive method in order to improve the abilities of classroom teachers and subject teachers in preparing lesson plans; and (2) improving the ability of class teachers and subject teachers in the preparation of lesson plans at SD Negeri 2 Trayu, Banyudono District, Boyolali Regency through academic supervision using a group approach with the directive method. This research is an action research. The research was conducted at SD Negeri 2 Trayu, Banyudono District, Boyolali Regency in the second semester of the 2020/2021 school year for 3 (three) months. The research subjects were 8 (eight) classroom teachers and subject teachers at SD Negeri 2 Trayu, Banyudono District, Boyolali Regency. The research procedure in this action research basically refers to the research design used, namely: (1) planning; (2) implementation; (3) observation; and (4) reflection on the results of the action. This study concludes that: (1) The steps for implementing academic supervision with a group approach with a directive method to improve the ability of teachers in the preparation of lesson plans are as follows: (a) Delivering announcements to teachers about academic supervision activities regarding improving teacher skills in the preparation of lesson plans; (b) Preparing guidance material in the form of syllabus and lesson plans in accordance with Curriculum 13; (c) Delivering guidance material on how to properly compile syllabus and lesson plans according to Curriculum 13; and (d) Prepare supervision instruments, both interview instruments and observation instruments; (2) Academic supervision with a group approach with the directive method can improve classroom teachers and subject teachers in the preparation of lesson plans at SD Negeri 2 Trayu, Banyudono District, Boyolali Regency. This is indicated by the increase in the average value of the RPP assessment results obtained by the teacher and the number of teachers with the ability to compile RPP categories Very Good (A) and Good (B) in each cycle of actions taken. The average value of the RPP assessment results has increased from 67.95 in the initial conditions, increased to 74.55 in the Cycle I action, and then increased to 81.12 in the Cycle II action. The number of teachers with the ability to compile RPP categories Very Good (A) and Good (B) has increased from as much as $31.25 \%$ in the initial conditions, increased to $50.00 \%$ in Cycle I actions, then increased to $81.25 \%$ in Cycle II actions.
\end{abstract}

Keywords: RPP preparation, academic supervision, group approach, directive method

\section{Pendahuluan}

Keberhasilan suatu lembaga pendidikan ditentukan oleh berbagai faktor. Salah satunya adalah sumberdaya ketenagaan yang mampu melaksanakan tugas dan tanggungiawabnya dengan baik. Pelaksanaan tugas guru yang optimal dan sesuai dengan tugas dan tanggungiawabnya merupakan penentu keberhasilan bagi peserta didik, yang kemudian menjadi parameter keberhasilan lembaga pendidikan. Suatu kegiatan pembelajaran yang berhasil tentunya ditunjang oleh beberapa hal dimulai dari persiapan pembelajaran, pelaksanaan pembelajaran, sampai dengan evaluasi pelaksanaan pembelajaran, serta diteruskan dengan tindak lanjut (Suwarto, 2009). Semua kegiatan 
tersebut mutlak harus dilaksanakan secara berkesinambungan dan terstruktur (Suwarto, 2017). Tahapan demi tahapan kegiatan dilaksanakan secara utuh dan menyeluruh. Kegiatan pembelajaran baru akan dapat dilaksanakan setelah persiapan pembelajaran disusun. Pembelajaran tanpa adanya persiapan, tidak akan ada tujuan dan arah serta kegiatan pembelajaran Pembelajaran akan terkesan asal-asalan, serta sulitnya mengukur keberhasilan siswa. Kondisi yang bertolak belakang terjadi di berbagai Sekolah Dasar (SD), dimana banyak ditemukan guru yang tidak menyusun RPP dalam pembelajaran yang dilakukan. Hal yang sama terjadi pula di SD Negeri 2 Trayu Kecamatan Banyudono Kabupaten Boyolali. Di sekolah ini banyak guru yang tidak membuat RPP. Kalaupun membuat, maka pembuatan RPP tidak sesuai dengan standar umum RPP (berdasarkan komponen-komponen RPP), dan RPP tidak lengkap. Ketika diadakan wawancara terhadap para guru di SD Negeri 2 Trayu Kecamatan Banyudono Kabupaten Boyolali disimpulkan bahwa masalah-masalah di atas disebabkan terdapatnya perbedaan pemahaman tentang penyusunan RPP. Terdapatnya guru yang kurang memahami cara penyusunan RPP dan guru malas dalam menyusun RPP. Serta kurangnya pembinaan dalam penyusunan RPP.

Guna mengatasi permasalahan tersebut diperlukan suatu upaya perbaikan yang harus dilakukan kepala sekolah. Hal ini salah satunya adalah melalui tindakan supervisi akademik dengan pendekatan kelompok. Tindakan supervisi merupakan bantuan yang diberikan kepada seluruh staf sekolah untuk mengembangkan situasi belajar-mengajar yang lebih baik. Melalui tindakan tersebut diharapkan guru dapat meningkatkan profesionalisme kerja mereka yang ditunjukkan dengan kemampuan dan kemauan dalam menyusun RPP bagi pembelajaran yang mereka lakukan. Dalam pedoman pelaksanaan kurikulum Sekolah Dasar dan Sekolah Menengah (Depdikbud, 2005:25), pengertian Supervisi dirumuskan sebagai bantuan yang diberikan kepada seluruh staf sekolah untuk mengembangkan situasi belajar-mengajar yang lebih baik. Burton dan Bruckner (dalam Daryanto 2013:2) mengembangkan definisi sebagai berikut: "Supervisi merupakan pelayanan yang bertujuan untuk mempelajari dan memperbaiki faktor-faktor yang mempengaruhi pertumbuhan dan perkembangan anak".

Acheson dan Gall (dalam Daryanto 2013:3) merumuskan bahwa. "Supervisi merupakan bantuan kepada guru untuk memperkecil kesenjangan antara tingkah laku mengajar yang nyata dan tingkah laku mengajar yang ideal". Sedangkan Alfonso (dalam Daryanto 2013:3) mengemukakan: "Supervisi pengajaran adalah perbuatan yang secara langsung mempengaruhi perilaku guru dalam melaksanakan tugasnya sebagai pelaksana proses belajar mengajar dan melalui pengaruhnya tersebut bertujuan untuk mempertinggi kualitas belajar murid demi pencapaian tujuan organisasi (sekolah)". Supandi (1996: 252), menyatakan bahwa ada dua hal yang mendasari pentingnya supervisi dalam proses pendidikan, yaitu: a) Perkembangan kurikulum merupakan gejala kemajuan pendidikan. elaksanaan kurikulum tersebut memerlukan penyesuaian yang terus-menerus dengan keadaan nyata di lapangan. Hal ini berarti bahwa guru-guru senantiasa harus berusaha mengembangkan kreativitasnya agar daya upaya pendidikan berdasarkan kurikulum dapat terlaksana secara baik; dan b) Pengembangan personel, pegawai atau karyawan senantiasa merupakan upaya yang terus-menerus dalam suatu organisasi. Pengembangan personal dapat dilaksanakan secara formal dan informal. Pengembangan formal menjadi tanggung jawab lembaga yang bersangkutan melalui penataran, tugas belajar, lokakarya dan sejenisnya. Sedangkan pengembangan informal merupakan tanggung jawab pegawai sendiri dan dilaksanakan secara mandiri atau bersama dengan rekan kerjanya, melalui 
berbagai kegiatan seperti kegiatan ilmiah, percobaan suatu metode mengajar, dan lain sebagainya.

Menurut Alfonso, Firth, dan Neville (dalam Daryanto 2013:195) supervisi akademik yang baik adalah supervisi yang mampu berfungsi mencapai multi tujuan tersebut di atas. Tidak ada keberhasilan bagi supervisi akademik jika hanya memerhatikan salah satu tujuan tertentu dengan mengesampingkan tujuan lainnya. Hanya dengan merefleksi ketiga tujuan inilah supervisi akademik akan berfungsi mengubah perilaku mengajar guru. Pada gilirannya nanti perubahan perilaku guru ke arah yang lebih berkualitas akan menimbulkan perilaku belajar murid yang lebih baik. Alfonso, Firth, dan Neville mengemukakan bahwa perilaku supervisi akademik secara langsung berhubungan dan berpengaruh terhadap perilaku guru. Mengacu pada latar belakang permasalahan di atas, maka permasalahan dalam penelitian tindakan ini dapat dirumuskan sebagai berikut: Bagaimana pelaksanaan supervisi akademik dengan pendekatan kelompok metode direktif meningkatkan kemampuan guru kelas dan guru mata pelajaran dalam penyusunan RPP di SD Negeri 2 Trayu Kecamatan Banyudono Kabupaten Boyolali dilakukan. Apakah supervisi akademik dengan pendekatan kelompok metode direktif dapat meningkatkan kemampuan guru kelas dan guru mata pelajaran dalam penyusunan RPP di SD Negeri 2 Trayu Kecamatan Banyudono Kabupaten Boyolali. Tujuan penelitian tindakan ini adalah untuk mendeskripsikan pelaksanaan supervisi akademik dengan pendekatan kelompok metode direktif meningkatkan kemampuan guru kelas dan guru mata pelajaran dalam penyusunan RPP di SD Negeri 2 Trayu Kecamatan Banyudono Kabupaten Boyolali, meningkatkan kemampuan guru kelas dan guru mata pelajaran dalam penyusunan RPP di SD Negeri 2 Trayu Kecamatan Banyudono Kabupaten Boyolali melalui supervisi akademik dengan pendekatan kelompok metode direktif.

\section{Metode Penelitian}

Sesuai dengan permasalahan dalam penelitian, maka penelitian dilakukan di SD Negeri 2 Trayu Kecamatan Banyudono Kabupaten Boyolali. Dipilihnya SD Negeri 2 Trayu Kecamatan Banyudono Kabupaten Boyolali sebagai tempat penelitian didasarkan pada adanya fakta bahwa guru-guru di sekolah tersebut belum mempunyai kemampuan menyusun RPP secara optimal. Subyek penelitian ini adalah guru-guru kelas dan guru mata pelajaran di SD Negeri 2 Trayu Kecamatan Banyudono Kabupaten Boyolali dengan jumlah sebanyak 8 orang guru. Sedangkan objek penelitian berupa supervisi akademik dalam meningkatkan kemampuan guru dalam penyusunan RPP yang dilakukan kepala sekolah di SD Negeri 2 Trayu Kecamatan Banyudono Kabupaten Boyolali guna meningkatkan kemampuan guru dalam penyusunan RPP. Teknik pengumpulan data dilakukan dengan menggunakan teknik wawancara, observasi, dan dokumen. Sumber data yang paling penting dalam penelitian kualitatif adalah berupa manusia yang berada dalam posisi sebagai nara sumber atau informan. Untuk mengumpulkan informasi dari sumber data ini diperlukan teknik wawancara. Tujuan utama teknik ini menurut Sutopo (2006: 68) adalah untuk bisa menyajikan konstruksi saat sekarang dalam suatu konteks mengenai para pribadi, peristiwa, aktivitas, organisasi, perasaan, motivasi, tanggapan, tingkat keterlibatan dan sebagainya. Dalam wawancara ini dilakukan dengan cara mengadakan komunikasi langsung dengan pihak-pihak yang dapat mendukung diperolehnya data yang berkaitan dengan permasalahan yang diteliti guna memperoleh data baik lisan ataupun tulisan atas sejumlah data yang diperlukan. Teknik Observasi digunakan untuk menggali data dari sumber data yang berupa peristiwa, aktivitas, perilaku, tempat atau lokasi dan benda serta rekaman gambar (Sutopo, 2006: 75). Observasi dapat dilakukan secara langsung maupun 
tidak langsung. Menurut Spradley (dalam Sutopo, 2006: 75) dikatakan bahwa pelaksanaan teknik observasi dapat dibagi menjadi: 1) observasi tidak berperan, dan 2) observasi berperan. Observasi dilakukan terhadap pelaksanaan kegiatan supervisi yang dilakukan kepala sekolah guna meningkatkan kemampuan guru dalam penyusunan RPP. Studi dokumen dilakukan dengan penelitian mengenai dokumen-dokumen yang berkaitan dengan kemampuan guru dalam penyusunan RPP yang dilakukan kepala sekolah di SD Negeri 2 Trayu Kecamatan Banyudono Kabupaten Boyolali. Alat pengumpulan data dalam penelitian ini terdiri dari panduan wawancara, catatan lapangan (lembar pengamatan), dan instrumen penilaian kemampuan penyusunan RPP. Panduan wawancara disusun untuk memudahkan penggalian informasi dari guru-guru baik sebelum maupun sesudah dilaksanakannya kegiatan supervisi. Adapun lembar pengamatan disusun untuk memudahkan pengumpulan data yang diperoleh dari hasil observasi. Instrumen penilaian RPP disusun berdasarkan aspek-aspek penilaian RPP yang terdiri dari 7 aspek. Ketujuh aspek tersebut terdiri dari aspek-aspek: a) Kemampuan merumuskan tujuan pembelajaran; b) Kemampuan mengorganisasikan bahan pembelajaran; c) Kemampuan menentukan strategi mengajar; d) Kemampuan menentukan langkah-langkah mengajar; e) Kemampuan menentukan alokasi waktu; f) Kemampuan menentukan sumber, media, dan alat; dan g) Kemampuan menentukan bentuk, prosedur, dan alat penilaian. Setiap aspek terdiri dari 4 deskriptor, sehingga penilaian dilakukan dengan menggunakan 28 deskriptor atau indikator. Skoring diberikan dengan rentang skor antara 1-5. Dengan demikian maka skor yang diperoleh guru adalah antara 28-140.

\section{Hasil Penelitian}

Kemampuan guru dalam penyusunan RPP pada kondisi awal diketahui dari hasil penilaian RPP yang dilakukan oleh kepala sekolah pada awal tahun ajaran baru. Penilaian dilakukan terhadap dokumen RPP yang disusun oleh guru menjelang kegiatan pembelajaran pada awal semester dilaksanakan. Penilaian dilakukan terhadap 7 aspek yang masing-masing aspek terdiri dari 4 deskriptor. Dengan demikian penilaian didasarkan pada 28 deskriptor. Skoring diberikan dengan rentang antara 1-5, sehingga skor yang diperoleh guru berkisar antara 28-140. Hasil skoring tersebut selanjutnya dikonversikan ke dalam bentuk nilai dengan skala 1-100. Berdasarkan hasil penilaian yang dilakukan terhadap RPP pada kondisi awal, dapat diketahui bahwa nilai terendah yang diperoleh guru adalah 64.29, sedangkan nilai tertinggi diperoleh sebesar 88.57. Nilai rata-rata diperoleh sebesar 69.73 . Mengingat nilai rata-rata tersebut terletak pada kategori cukup baik (C), maka kemampuan guru dalam menyusun RPP pada kondisi awal diklasifikasikan ke dalam kategori cukup baik. Data kemampuan guru dalam penyusunan RPP pada kondisi awal berdasarkan kategori dapat disajikan ke dalam tabel berikut ini.

Tabel 1. Kemampuan Guru dalam Penyusunan RPP Berdasar Kategori pada Kondisi Awal

\begin{tabular}{clcc}
\hline No. & \multicolumn{1}{c}{ Kategori } & Jumlah & $\%$ \\
1. & $\begin{array}{l}\text { Amat Baik (A) } \\
\text { (Nilai } \geq 85.00)\end{array}$ & 1 & $12,50 \%$ \\
2. & $\begin{array}{l}\text { Baik (B) } \\
\text { Nilai 75.00 }-<85.00)\end{array}$ & 1 & $12,50 \%$ \\
3. & $\begin{array}{l}\text { Cukup Baik (C) } \\
\text { (Nilai 68.57 }-<75.00)\end{array}$ & 2 & $25,00 \%$ \\
4. & $\begin{array}{l}\text { Kurang Baik (D) } \\
\text { Nilai }<68.57\end{array}$ & 4 & $50,00 \%$ \\
\hline
\end{tabular}




\begin{tabular}{ccc}
\hline Jumlah & 8 & $100,00 \%$ \\
\hline
\end{tabular}

Berdasarkan hasil pengamatan pada tabel di atas, dapat diketahui bahwa guru yang memiliki kemampuan penyusunan RPP dengan kategori Amat Baik (A) adalah sebanyak 1 orang guru atau $12.50 \%$ dari jumlah guru. Guru yang memiliki kemampuan penyusunan RPP dengan kategori Baik (B) adalah sebanyak 1 orang guru atau $12.50 \%$ dari jumlah guru. Guru yang memiliki kemampuan penyusunan RPP dengan kategori Cukup Baik (C) adalah sebanyak 2 orang guru atau $25.00 \%$ dari jumlah guru. Guru yang memiliki kemampuan penyusunan RPP dengan kategori Kurang Baik (D) adalah sebanyak 4 orang guru atau $50.00 \%$ dari jumlah guru. Data kemampuan guru dalam penyusunan RPP pada kondisi awal selanjutnya dapat disajikan ke dalam diagram sebagai berikut.

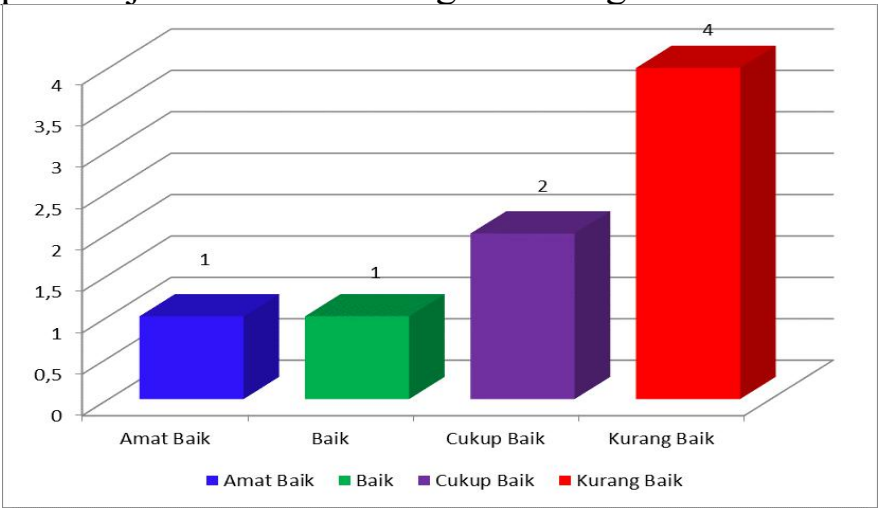

Gambar 1. Diagram Kemampuan Guru dalam Penyusunan RPP pada Kondisi Awal

Berdasarkan hasil penilaian tersebut, dapat diketahui bahwa jumlah guru yang memiliki kemampuan dalam menyusun RPP dengan kategori Amat Baik (A) dan Baik (B) baru mencapai 2 orang guru atau $25.00 \%$. Dengan demikian maka diperlukan adanya pembinaan melalui kegiatan supervisi akademik. Berdasarkan kinerja guru dalam kondisi awal tersebut, selanjutnya dilakukan tindakan berupa supervisi akademik dengan pendekatan kelompok. Tindakan dalam Siklus I mencakup empat tahap, yaitu perencanaan, pelaksanaan, pengamatan, dan refleksi hasil tindakan. Berdasarkan hasil penilaian, dapat diketahui bahwa nilai terendah yang diperoleh guru adalah sebesar 64.29. Nilai tertinggi diperoleh sebesar 92.86. Adapun nilai rata-rata diperoleh sebesar 77.50. Mengingat nilai rata-rata tersebut terletak pada kategori Cukup Baik (C), maka kemampuan guru dalam menyusun RPP pada tindakan Siklus I diklasifikasikan ke dalam kategori Cukup Baik (C). Data kemampuan guru dalam penyusunan RPP pada tindakan Siklus I berdasarkan kategori dapat disajikan ke dalam tabel berikut ini.

Tabel 2. Kemampuan Guru dalam Penyusunan RPP Berdasar Kategori pada Tindakan

Siklus I

\begin{tabular}{rlcc}
\hline No. & \multicolumn{1}{c}{ Kategori } & Jumlah & $\%$ \\
1. & $\begin{array}{l}\text { Amat Baik (A) } \\
(\text { Nilai } \geq 85.00)\end{array}$ & 3 & $37,50 \%$ \\
2. & $\begin{array}{l}\text { Baik (B) } \\
(\text { Nilai 75.00-<85.00) }\end{array}$ & 1 & $12,50 \%$ \\
3. & $\begin{array}{l}\text { Cukup Baik }(\mathrm{C}) \\
(\text { Nilai 68.57-<75.00) }\end{array}$ & 2 & $25,00 \%$ \\
\hline
\end{tabular}




$\begin{array}{llc}\text { 4. Kurang Baik (D) } & 2 & 25,00 \% \\ \text { Nilai }<68.57 & 8 & 100,00 \% \\ \text { Jumlah } & \end{array}$

Berdasarkan hasil pengamatan pada tabel di atas, dapat diketahui bahwa guru yang memiliki kemampuan penyusunan RPP dengan kategori Amat Baik (A) adalah sebanyak 3 orang guru atau $37.50 \%$ dari jumlah guru. Guru yang memiliki kemampuan penyusunan RPP dengan kategori Baik (B) adalah sebanyak 1 orang guru atau $12.50 \%$ dari jumlah guru. Guru yang memiliki kemampuan penyusunan RPP dengan kategori Cukup Baik (C) adalah sebanyak 2 orang guru atau $25.00 \%$ dari jumlah guru. Guru yang memiliki kemampuan penyusunan RPP dengan kategori Kurang Baik (D) adalah sebanyak 2 orang guru atau $25.00 \%$ dari jumlah guru. Hasil-hasil tersebut menunjukkan bahwa kemampuan guru dalam penyusunan RPP pada tindakan Siklus I mengalami peningkatan dibandingkan dengan kondisi sebelumnya. Hal tersebut dapat diketahui dari meningkatnya nilai rata-rata hasil penilaian maupun dari banyaknya guru yang sudah memperoleh nilai dengan klasifikasi Amat Baik (A) dan Baik (B). Data kemampuan guru dalam penyusunan RPP pada tindakan Siklus I selanjutnya dapat disajikan ke dalam diagram sebagai berikut.

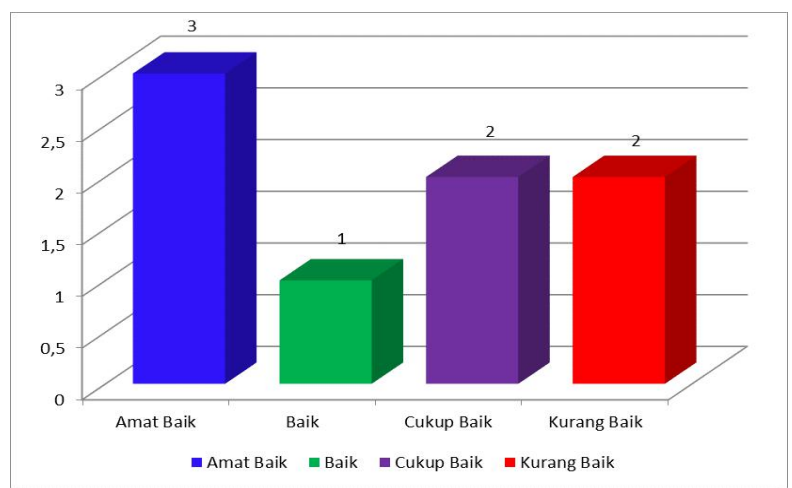

Gambar 2. Diagram Kemampuan Guru dalam Penyusunan RPP pada Tindakan Siklus I

Berdasarkan hasil-hasil yang sudah dicapai pada tindakan supervisi Siklus I di atas, selanjutnya dapat dikemukakan refleksi sebagai berikut: Supervisi akademik dengan pendekatan kelompok metode direktif dapat meningkatkan kemampuan guru dalam penyusunan RPP. Hal ini ditunjukkan dengan meningkatnya nilai rata-rata hasil penilaian RPP yang diperoleh guru maupun jumlah guru dengan kemampuan menyusun RPP kategori Amat Baik (A) dan Baik (B) dibandingkan kondisi sebelumnya. Nilai rata-rata hasil penilaian RPP mengalami peningkatan dari sebesar 69.73 pada kondisi awal, meningkat menjadi 83.57 pada tindakan Siklus I. Jumlah guru dengan kemampuan menyusun RPP kategori Amat Baik (A) dan Baik (B) mengalami peningkatan dari sebanyak $25.00 \%$ pada kondisi awal, meningkat menjadi $50.00 \%$ pada tindakan Siklus I. Peningkatan yang diperoleh pada tindakan Siklus I masih belum optimal. Hal ini ditunjukkan dengan belum tercapainya indikator kinerja berupa nilai rata-rata hasil penilaian termasuk ke dalam kategori Baik (B), yaitu dengan rentang skor $\geq 75.00$, dan banyaknya guru yang sudah memperoleh nilai $\geq 75.00$ mencapai $\geq 80.00 \%$ dari jumlah guru. Kelemahan yang masih ada pada guru dalam penyusunan RPP adalah pada aspek mengorganisasikan materi, menentukan langkah-langkah mengajar, dan menentukan bentuk, prosedur, dan alat penilaian. Dengan demikian maka diperlukan perbaikan pada aspek-aspek tersebut pada tindakan Siklus II. 
Nilai terendah yang diperoleh guru adalah sebesar 68.57, dan nilai tertinggi diperoleh sebesar 95.71. Adapun nilai rata-rata diperoleh sebesar 85.80. Mengingat nilai rata-rata tersebut terletak pada kategori Baik (B), maka kemampuan guru dalam menyusun RPP pada tindakan Siklus II diklasifikasikan ke dalam kategori Baik (B). Data kemampuan penilaian kualitas RPP yang disusun guru pada tindakan Siklus II dapat disajikan sebagai berikut:

Tabel 3. Kemampuan Guru dalam Penyusunan RPP Berdasar Kategori pada Tindakan

Siklus II

\begin{tabular}{llcc}
\hline No. & \multicolumn{1}{c}{ Kategori } & Jumlah & $\%$ \\
1. & $\begin{array}{l}\text { Amat Baik (A) } \\
\text { (Nilai } \geq 85.00)\end{array}$ & 5 & $62,50 \%$ \\
2. & $\begin{array}{l}\text { Baik (B) } \\
\text { (Nilai 75.00-<85.00) }\end{array}$ & 2 & $25,00 \%$ \\
3. & $\begin{array}{l}\text { Cukup Baik (C) } \\
\text { (Nilai 68.57 }-<75.00)\end{array}$ & 1 & $12,50 \%$ \\
4. & $\begin{array}{l}\text { Kurang Baik (D) } \\
\text { Nilai }<68.57\end{array}$ & 0 & $0,00 \%$ \\
Jumlah & 8 & $100,00 \%$ \\
\hline
\end{tabular}

Berdasarkan hasil pengamatan pada tabel di atas, dapat diketahui bahwa guru yang memiliki kemampuan penyusunan RPP dengan kategori Amat Baik (A) adalah sebanyak 5 orang guru atau $62.50 \%$ dari jumlah guru. Guru yang memiliki kemampuan penyusunan RPP dengan kategori Baik (B) adalah sebanyak 2 orang guru atau 25.00\% dari jumlah guru. Guru yang memiliki kemampuan penyusunan RPP dengan kategori Cukup Baik (C) adalah sebanyak 1 orang guru atau $12.50 \%$ dari jumlah guru. Guru yang memiliki kemampuan penyusunan RPP dengan kategori Kurang Baik (D) sudah tidak ada. Data kemampuan guru dalam penyusunan RPP pada tindakan Siklus II selanjutnya dapat disajikan ke dalam diagram sebagai berikut.

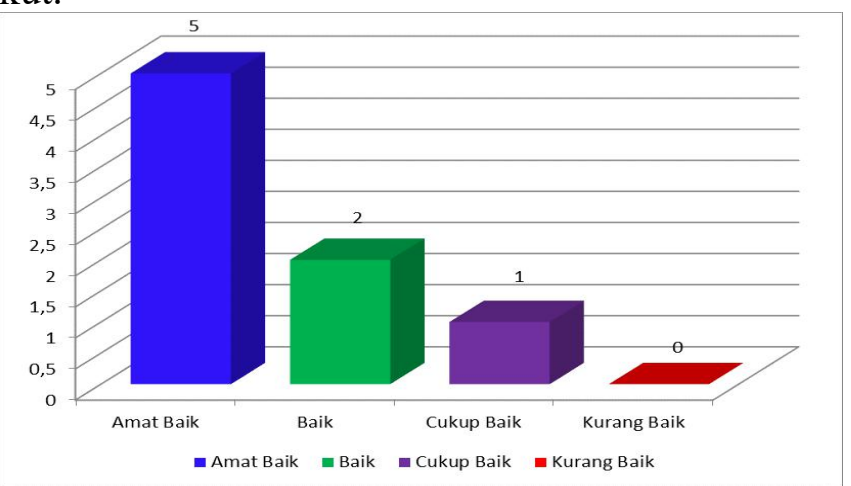

Gambar 3. Diagram Kemampuan Guru dalam Penyusunan RPP pada Tindakan Siklus II

Berdasarkan hasil-hasil yang diperoleh pada tindakan Siklus II, selanjutnya dapat dikemukakan refleksi hasil tindakan sebagai berikut: Supervisi akademik dengan pendekatan kelompok metode direktif dapat meningkatkan kemampuan guru dalam penyusunan RPP. Hal ini ditunjukkan dengan meningkatnya nilai rata-rata hasil penilaian RPP yang diperoleh guru maupun jumlah guru dengan kemampuan menyusun RPP kategori Amat Baik (A) dan Baik (B) dibandingkan kondisi sebelumnya. Nilai rata-rata hasil penilaian RPP mengalami peningkatan dari sebesar 83.57 pada tindakan Siklus I, 
meningkat menjadi 85.80 pada tindakan Siklus II. Jumlah guru dengan kemampuan menyusun RPP kategori Amat Baik (A) dan Baik (B) mengalami peningkatan dari sebanyak $50.00 \%$ pada tindakan Siklus I, meningkat menjadi $87.50 \%$ pada tindakan Siklus II. Hal-hal yang belum tercapai pada tindakan Siklus I, yaitu berupa: a) nilai rata-rata hasil penilaian masih $<75.00$, dan b) banyaknya guru yang sudah memperoleh nilai $\geq 75.00$ mencapai $\geq 80.00 \%$ dari jumlah guru, sudah terpenuhi pada tindakan Siklus II. Nilai ratarata hasil penilaian sudah mencapai kategori Baik (B), yaitu dengan nilai 85.80. Adapun banyaknya guru yang sudah memperoleh nilai $\geq 75.00$ sudah mencapai $87.50 \%$ dari jumlah guru. Atas dasar hal tersebut maka dapat disimpulkan bahwa supervisi akademik dengan pendekatan kelompok metode direktif dapat meningkatkan kemampuan guru dalam penyusunan RPP.

\section{Pembahasan}

Hipotesis yang menyatakan bahwa "supervisi akademik dengan pendekatan kelompok metode direktif dapat meningkatkan guru kelas dan guru mata pelajaran dalam penyusunan RPP di SD Negeri 2 Trayu Kecamatan Banyudono Kabupaten Boyolali” terbukti kebenarannya. Hal ini ditunjukkan dengan meningkatnya nilai rata-rata hasil penilaian RPP yang diperoleh guru maupun jumlah guru dengan kemampuan menyusun RPP kategori Amat Baik (A) dan Baik (B) pada setiap siklus tindakan yang dilakukan. Kemampuan guru dalam penyusunan RPP pada kondisi awal masih belum optimal. Hal ini ditunjukkan dengan nilai rata-rata hasil penilaian sebesar 69.73 yang berada pada rentang kategori Cukup Baik (C). Jumlah guru yang sudah mempunyai kemampuan dalam penyusunan RPP dengan kategori Amat Baik (A) dan Baik (B) baru mencapai sebanyak $25.00 \%$. Berangkat dari kondisi tersebut, maka kepala sekolah selaku supervisor perlu melakukan pembinaan. Pembinaan yang dilakukan adalah dengan melaksanakan kegiatan supervisi akademik dengan pendekatan kelompok. Adapun metode yang digunakan adalah metode direktif.

Upaya perbaikan yang dilakukan kepala sekolah melalui supervisi akademik pendekatan kelompok dengan metode direktif pada tindakan Siklus I berhasil meningkatkan kemampuan guru dalam penyusunan RPP. Hal ini ditunjukkan dengan meningkatnya nilai rata-rata hasil penilaian RPP yang diperoleh guru maupun jumlah guru dengan kemampuan menyusun RPP kategori Amat Baik (A) dan Baik (B) dibandingkan kondisi sebelumnya. Nilai rata-rata hasil penilaian RPP mengalami peningkatan dari sebesar 69.73 pada kondisi awal, meningkat menjadi 83.57 pada tindakan Siklus I. Jumlah guru dengan kemampuan menyusun RPP kategori Amat Baik (A) dan Baik (B) mengalami peningkatan dari sebanyak $25.00 \%$ pada kondisi awal, meningkat menjadi $50.00 \%$ pada tindakan Siklus II.

Peningkatan yang diperoleh pada tindakan Siklus I masih belum optimal. Hal ini ditunjukkan dengan belum tercapainya indikator kinerja berupa nilai rata-rata hasil penilaian termasuk ke dalam kategori Baik (B), yaitu dengan rentang skor $\geq 75.00$, dan banyaknya guru yang sudah memperoleh nilai $\geq 75.00$ mencapai $\geq 80.00 \%$ dari jumlah guru. Kelemahan yang masih ada pada guru dalam penyusunan RPP adalah pada aspek mengorganisasikan materi, menentukan langkah-langkah mengajar, dan menentukan bentuk, prosedur, dan alat penilaian. Dengan demikian maka diperlukan perbaikan pada aspek-aspek tersebut pada tindakan Siklus II. Upaya perbaikan yang dilakukan kepala sekolah pada tindakan Siklus II berhasil meningkatkan kemampuan guru dalam menyusun RPP. Hal ini ditunjukkan dengan meningkatnya nilai rata-rata hasil penilaian RPP yang diperoleh guru maupun jumlah guru dengan kemampuan menyusun RPP kategori Amat Baik (A) dan Baik (B) dibandingkan kondisi sebelumnya. 
Nilai rata-rata hasil penilaian RPP mengalami peningkatan dari sebesar 83.57 pada tindakan Siklus I, meningkat menjadi 85.80 pada tindakan Siklus II. Jumlah guru dengan kemampuan menyusun RPP kategori Amat Baik (A) dan Baik (B) mengalami peningkatan dari sebanyak $50.00 \%$ pada tindakan Siklus I, meningkat menjadi $87.50 \%$ pada tindakan Siklus II. Peningkatan kemampuan guru dalam penyusunan RPP dari tahap pra siklus tindakan hingga akhir tindakan Siklus II selanjutnya dapat diringkaskan ke dalam tabel berikut.

Tabel 4. Peningkatan Kemampuan Guru dalam Penyusunan RPP

\begin{tabular}{|c|c|c|c|c|c|c|c|}
\hline \multirow{2}{*}{ No. } & \multirow{2}{*}{ Kategori } & \multicolumn{2}{|c|}{ Awal } & \multicolumn{2}{|c|}{ Siklus I } & \multicolumn{2}{|c|}{ Siklus II } \\
\hline & & $\mathrm{Jml}$ & $\%$ & $\mathrm{Jml}$ & $\%$ & $\mathrm{Jml}$ & $\%$ \\
\hline 1. & $\begin{array}{l}\text { Amat Baik (A) } \\
(\text { Nilai } \geq 85.00)\end{array}$ & 1 & $12,50 \%$ & 3 & $37,50 \%$ & 5 & $62,50 \%$ \\
\hline 2. & $\begin{array}{l}\text { Baik (B) } \\
\text { (Nilai } 75.00-<85.00)\end{array}$ & 1 & $12,50 \%$ & 1 & $12,50 \%$ & 2 & $25,00 \%$ \\
\hline 3. & $\begin{array}{l}\text { Cukup Baik }(C) \\
\text { (Nilai } 68.57-<75.00)\end{array}$ & 2 & $25,00 \%$ & 2 & $25,00 \%$ & 1 & $12,50 \%$ \\
\hline 4. & $\begin{array}{l}\text { Kurang Baik (D) } \\
\text { Nilai }<68.57\end{array}$ & 4 & $50,00 \%$ & 2 & $25,00 \%$ & 0 & $0,00 \%$ \\
\hline & Jumlah & 8 & $100,00 \%$ & 8 & $100,00 \%$ & 8 & $100,00 \%$ \\
\hline
\end{tabular}

Kemampuan guru dalam penyusunan RPP dari tahap pra siklus tindakan hingga akhir tindakan Siklus II selanjutnya dapat disajikan ke dalam diagram berikut.

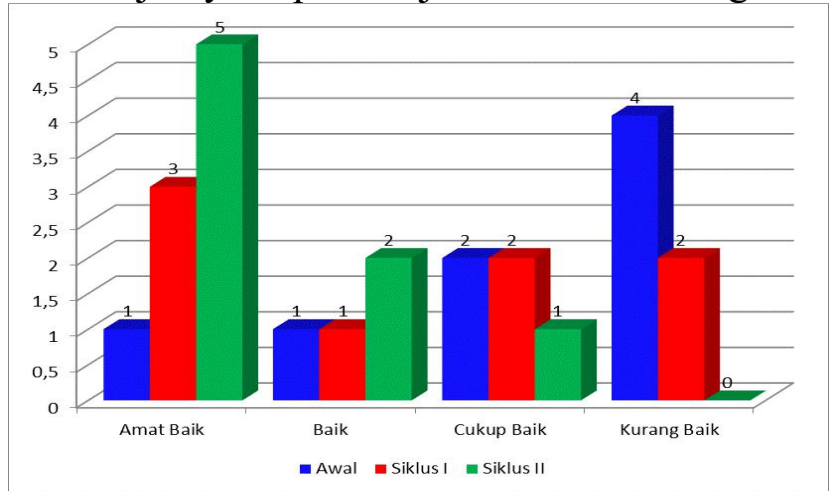

Gambar 4. Diagram Peningkatan Kemampuan Guru dalam Penyusunan RPP

Kegiatan supervisi akademik merupakan salah satu kegiatan pembinaan dengan memberi bantuan teknis kepada guru dalam melaksanakan proses pembelajaran, yang bertujuan untuk meningkatkan kemampuan profesional guru dan meningkatkan kualitas pembelajaran. Supervisi akademik sebaiknya dilakukan dengan pendekatan supervisi klinis yang dilaksanakan secara berkesinambungan melalui tahapan pra-observasi, observasi pembelajaran, dan pasca observasi. Untuk meningkatkan kemampuan guru dalam penyusunan perangkat pembelajaran, supervisi akademis yang dilakukan kepala sekolah dalam meningkatkan kemampuan guru dalam penyusunan RPP dan silabus berhasil meningkatkan kemampuan guru dalam penyusunan perangkat pembelajaran. Peningkatan kemampuan tersebut ditunjukkan dengan meningkatnya kualifikasi penilaian yang diperoleh guru pada setiap tindakan yang dilakukan.

Adanya peningkatan dalam hal kinerja guru pada setiap siklus tindakan menunjukkan bahwa supervisi yang dilakukan secara tepat akan lebih optimal. Langkah perbaikan yang dilakukan kepala sekolah pada setiap siklus tindakan yang dilakukan efektif 
dalam meningkatkan kemampuan guru sesuai fokus dan penekanan bimbingan yang dilakukan. Hasil tersebut sesuai dengan konsep utama supervisi akademik menurut Glickman (dalam Purwanto, 2004) yang menjelaskan bahwa supervisi akademik adalah serangkaian kegiatan membantu guru mengembangkan kemampuannya mengelola proses pembelajaran demi pencapaian tujuan pembelajaran Glickman (1981). Berdasarkan penjelasan tersebut dapat diartikan bahwa supervisi akademik merupakan upaya membantu guru-guru mengembangkan kemampuannya mencapai tujuan pembelajaran. Dengan demikian, esensi supervisi akademik itu sama sekali bukan menilai unjuk kerja guru dalam mengelola proses pembelajaran, melainkan membantu guru mengembangkan kemampuan profesionalismenya.

Meskipun demikian, supervisi akademik tidak bisa terlepas dari penilaian unjuk kerja guru dalam mengelola pembelajaran. Apabila di atas dikatakan, bahwa supervisi akademik merupakan serangkaian kegiatan membantu guru mengembangkan kemampuannya mengelola proses pembelajaran, maka menilai unjuk kerja guru dalam mengelola proses pembelajaran merupakan salah satu kegiatan yang tidak bisa dihindarkan prosesnya (Sergiovanni, 1987). Penilaian unjuk kerja guru dalam mengelola proses pembelajaran sebagai suatu proses pemberian estimasi kualitas unjuk kerja guru dalam mengelola proses pembelajaran, merupakan bagian integral dari serangkaian kegiatan supervisi akademik.

\section{Simpulan dan Saran}

Pelaksanaan supervisi akademik dengan pendekatan kelompok metode direktif untuk meningkatkan kemampuan guru dalam penyusunan RPP dilakukan melalui dua siklus tindakan. Langkah-langkah yang dilakukan antara lain adalah Menyampaikan pengumuman kepada guru tentang akan dilaksanakannya kegiatan supervisi akademik mengenai peningkatan kemampuan guru dalam penyusunan RPP, Mempersiapkan materi bimbingan berupa penyusunan silabus dan RPP sesuai dengan Kurikulum 13, Menyampaikan materi bimbingan tentang cara penyusunan silabus dan RPP sesuai dengan Kurikulum 13 dengan benar, Mempersiapkan instrumen supervisi baik instrumen wawancara maupun instrumen pengamatan. Supervisi akademik dengan pendekatan kelompok metode direktif dapat meningkatkan guru kelas dan guru mata pelajaran dalam penyusunan RPP di SD Negeri 2 Trayu Kecamatan Banyudono Kabupaten Boyolali. Hal ini ditunjukkan dengan meningkatnya nilai rata-rata hasil penilaian RPP yang diperoleh guru maupun jumlah guru dengan kemampuan menyusun RPP kategori Amat Baik (A) dan Baik (B) pada setiap siklus tindakan yang dilakukan. Nilai rata-rata hasil penilaian RPP mengalami peningkatan dari sebesar 69.73 pada kondisi awal, meningkat menjadi 83.57 pada tindakan Siklus I, dan kemudian meningkat menjadi 85.80 pada tindakan Siklus II. Jumlah guru dengan kemampuan menyusun RPP kategori Amat Baik (A) dan Baik (B) mengalami peningkatan dari sebanyak $25.00 \%$ pada kondisi awal, meningkat menjadi $50.00 \%$ pada tindakan Siklus I, kemudian meningkat menjadi $87.50 \%$ pada tindakan Siklus II.

Hasil penelitian menunjukkan bahwa supervisi yang dilakukan secara sistematis mampu meningkatkan kemampuan bagi guru. Untuk itu disarankan kepada kepala sekolah agar dalam melakukan supervisi akademik dilakukan secara konstruktif dan mendukung peningkatan kinerja guru.. Kegiatan supervisi akademik yang dilakukan kepala sekolah bukanlah untuk mencari kesalahan guru, untuk itu disarankan kepada para guru agar dapat memanfaatkan kegiatan supervisi guna meningkatkan kemampuan dalam peningkatan profesionalisme mereka. 


\section{Daftar Rujukan}

Ardian dkk, (2020). Pemanfaatan Microsoft Sway dan Microsoft Form Sebagai Media Interaktif Dalam Pembelajaran Sejarah. Diambil dari:

http://jurnal.unsil.ac.id/index.php/bihari/article/view/2520.

Arikunto, Suharsimi dkk. (2007). Metode Penelitian: Suatu Pendekatan Praktik. Jakarta: PT. Rineka Cipta.

Arikunto, Suharsimi. (1988). Dasar-Dasar Evaluasi Pendidikan. Jakarta: Bina Aksara.

Asep H. Hermawan, dkk. (2008). Pembangunan Kurikulum dan Pembelajaran. Jakarta: Universitas Terbuka.

Astuti dkk, (2020). Pelatihan Pembelajaran Microsoft 365 Pada Guru Sekolah Dasar Negeri 02 Banjarturi Warureja Tegal. Diambil dari:

https://kkn.unnes.ac.id/lapkknunnes/32004_3328162011_6_Desa\%20Bojongsana_2 0200909_140554.pdf.

Depdiknas. (2005). Standar Nasional Pendidikan. Jakarta: Direktorat Pendidikan Lanjutan Pertama Dirjen Dikdasmen.

Fathimatuzzahrah, Ainin. (2020). Keefektifan Layanan Bimbingan Klasikal Dengan Teknik STAD Untuk Meningkatkan Kemampuan Kerjasama Dalam Penyelesaian Studi Siswa. Jurnal Basic Edu, Volume 2(1), April 2020, hal: 1-7

Fatimah, Dewi Nur. (2017). Layanan Bimbingan Klasikal Dalam Meningkatkan Self Control Siswa SMP Negeri 5 Yogyakarta. Jurnal Bimbingan Konseling dan Dakwah Islam, volume 14(1), hal: 28- 29

Glickman. (1990). Supervision Human and Perspective. Macmilan: New York

Mulyasa. (2007). Menjadi Guru Profesional.. Bandung: Remaja Rosdakarya.

Purwanto, Ngalim. (2003). Administrasi dan Supervisi Pendidikan. Bandung: PT. Remaja Rosda Karya.

Suryosubroto. (2004). Manajemen Pendidikan di Sekolah. Jakarta: Rineka Cipta.

Sutopo, HB. (2006). Metode Penelitian Kualitatif, Surakarta: UNS Press.

Suprihatin MD. (1989). Administrasi Pendidikan. Fungsi dan Tanggung Jawab Kepala Sekolah sebagai Administrator dan Supervisor Sekokah. Semarang: IKIP Semarang Press.

Supandi. (1996). Administrasi dan Supervisi Pendidikan. Jakarta Departemen Agama dan Universitas Terbuka.

Suwarto, S. (2009). Pengembangan tes dan analisis hasil tes yang terintegrasi dalam program komputer. Jurnal Penelitian dan Evaluasi Pendidikan, 13(1), 40-56.

Suwarto, S. (2017). Pengembangan tes ilmu pengetahuan alam terkomputerisasi. Jurnal Penelitian dan Evaluasi Pendidikan, 21(2), 153-161. 